\title{
Stock Structure Delineation of the African Catfish (Clarius gariepinus) in Selected Populations in Kenya Using Mitochondrial DNA (Dloop) Variability
}

Cynthia Nyunja ${ }^{1 *}$, Joyce Maina ${ }^{1}$, Joshua Amimo', Felix Kibegwa', David Harper ${ }^{1,2}$ and Joseph Jung'a ${ }^{1}$

${ }^{1}$ Department of Animal Production, University of Nairobi, Kenya

${ }^{2}$ University of Leicester, England

\begin{abstract}
This study genetically characterized five populations of the African catfish (Clarius gariepinus) in Kenya. Samples were obtained from five sites in the country-Athi River hatchery, Kisii Fingerling Production Centre (FPC), Jewlett hatchery, Sagana Hatchery Station and Lake Baringo. DNA was extracted from tissue samples, followed by amplification and sequencing of the dloop region. Haplotype diversities, phylogenetic structure and variation at the dloop region of mitochondrial DNA were assessed.

Mitochondrial DNA analyses indicated that the sampled species showed genetic diversity between its populations. The genetic results were congruent indicating the differences in diversities and haplotype similarities of catfish samples from different sites. The Sagana, Kisii FPC, Jewlett and Baringo population cluster overlapped indicating possibly shared source of brood stock. The Athi river population was in a different cluster and its distinctiveness is attributed to imported brood stock. Both Athi River hatchery and Lake Baringo populations were highly variable and has great potential for production.
\end{abstract}

Keywords: Clarius gariepinus; Brood stock; Aquaculture

\section{Introduction}

The African catfish is an indigenous species in Kenya where it is widely cultured. Aquaculture in Kenya began with trout species mainly for recreational purposes [1], later tilapia species was cultured for food followed by the African catfish. C. gariepinus adapts well to artificial environments, and has rapidly gained status as an important aquaculture species [2]. The species have a rapid growth, a high reproductive potential and sturdy resistance to harsh environments as they have adaptive mechanisms. C. gariepinus as an aquaculture species has the advantage that it can be reared at a high stocking density without affecting fish survival [3]. The species now makes up a fifth of the total fish produced in the country [4]. This was a major result of the government's Economic Stimulus Programme in 2009 to encourage aquaculture production in Kenya [5]. There has been much interest in the culture of $C$. gariepinus to increase seed production and availability [5,6]. Many hatcheries have come up since 2009 and have been involved in artificial propagation of the species. Some of the hatcheries produce only fingerlings and some also produce table size catfish for consumption. However, there has been occasional losses by grow out farms due to poor quality seed supply and other stresses [7]. Hatcheries have faced many problems including identifying brood stock and structure of the populations.

Culture fish populations from hatcheries in Kenya with brood stock obtained from different sources; including natural water bodies; are heavily relied on by farmers for production. To increase the diversity of fish in fish farms [8] then more research needs to be undertaken to understand the population diversities. Molecular markers are used to characterize the population of catfish species proper identification $[6,9]$. Molecular tools such as mitochondrial DNA has been used to assess the phylogeny and haplotype variation of the African catfish in other studies. Mitochondrial variation assessments have enabled distinction of brood stock from wild populations for use by hatcheries in culturing populations and for phylogenetic trees [10]. Characterization of the populations was done using mitochondrial DNA in the current study. Mitochondrial DNA has some advantages over other tools for genetic analyses due to its maternal inheritance and fast mutation rate of the control region [11]. The objective was to ascertain genetic diversity and make recommendations for the sources of future farmed breeding stocks.

\section{Materials and Methods}

\section{Sampled sites}

African Catfish (C. gariepinus) samples were obtained from Lake Baringo and four hatcheries across the country as shown in Figure 1.

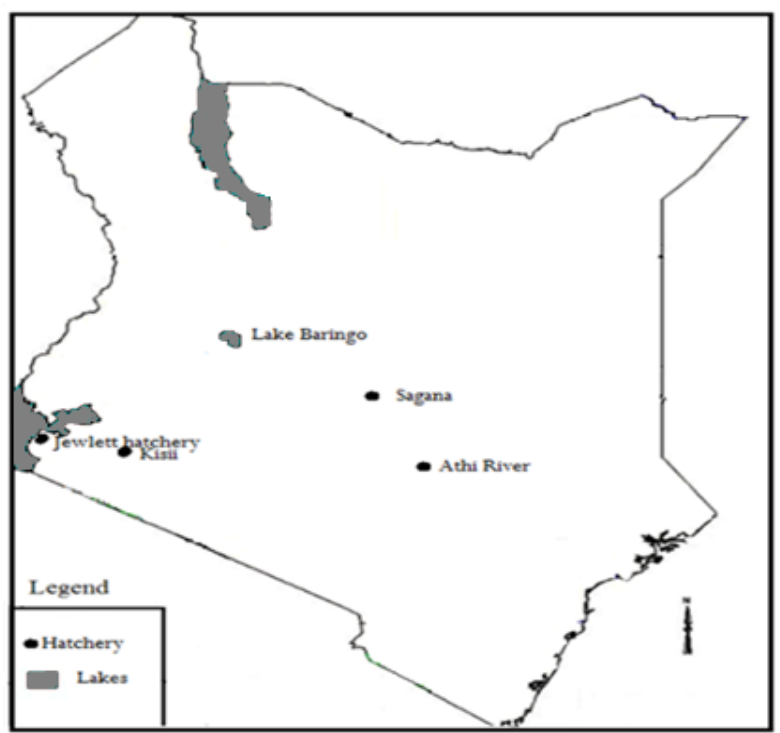

Figure 1: Kenyan map showing location of sampled sites.

*Corresponding author: Cynthia Nyunja, Department of Animal Production, University of Nairobi, Kenya, Tel: +254 20 318262; E-mail: cynyunja@yahoo.com

Received June 09, 2017; Accepted June 22, 2017; Published June 24, 2017

Citation: Nyunja C, Maina J, Amimo J, Kibegwa F, Harper D, et al. (2017) Stock Structure Delineation of the African Catfish (Clarius gariepinus) in Selected Populations in Kenya Using Mitochondrial DNA (Dloop) Variability. J Aquac Res Development 8: 485. doi: 10.4172/2155-9546.1000485

Copyright: $\odot 2017$ Nyunja C, et al. This is an open-access article distributed unde the terms of the Creative Commons Attribution License, which permits unrestricted use, distribution, and reproduction in any medium, provided the original author and source are credited. 
Citation: Nyunja C, Maina J, Amimo J, Kibegwa F, Harper D, et al. (2017) Stock Structure Delineation of the African Catfish (Clarius gariepinus) in Selected Populations in Kenya Using Mitochondrial DNA (Dloop) Variability. J Aquac Res Development 8: 485. doi: 10.4172/21559546.1000485

Page 2 of 6

Lake Baringo is located in Kenya in the Great Rift Valley at an altitude of $975 \mathrm{~m}$ [12] with a maximum depth of $12 \mathrm{~m}$. The lake has a surface area of approximately $130 \mathrm{~km}^{2}$ located north of Lake Bogoria. The lake is fed by rivers Molo and Perkerra. The lake has a number of introduced fish species. The marbled lungfish (Protopterus aethiopicus) an introduced species provides the majority of fish output from the lake. Fish composition in the lake include Clarius gariepinus and others such as Oreochromis niloticus, Protopterus aethiopicus, Barbus intermedius and Labeo cylindricus [13].

The hatcheries were:

- Athi River hatchery near Nairobi was established in 2013.

- Jewlett hatchery to Western part of Kenya was established in 2011.

- The Kisii Fingerling Production Centre is a government institution.

- Sagana Centre was established in 1948 and is a governmental research station in Kenya.

The samples size was as follows: Athi river hatchery (22) Kisii FPC (20) Jewlett hatchery (20) Sagana (8) and Lake Baringo (23). The sampled fish were adults bought at the hatchery locations. Lake Baringo samples were bought from the commercial fisheries landings beach. The tissue samples were preserved in $96 \%$ ethanol in $1.5 \mathrm{ml}$ tubes and transported to the University of Nairobi's Animal Production department genetics laboratory.

\section{DNA extraction and Polymerase Chain Reaction (PCR)}

The DNA extraction was done using the Qiagen extraction kit (Qiagen Valencia, CA USA) following the manufacturer's instructions with a few modifications. Twenty-five $\mathrm{mg}$ of catfish skeletal tissue was macerated, lysed and incubated for digestion at $56^{\circ} \mathrm{C}$ for 2 hours. Centrifugation for spinning down digested content was at $10000 \mathrm{rpm}$ except for the final wash which was done at $14000 \mathrm{rpm}$, Elution was done with $50 \mu \mathrm{l}$ of AE elution buffer for all the samples. Presence and quality of the extracted genomic DNA was assessed using $1 \%$ agarose gel electrophoresis.

Amplification of the targeted mitochondrial region in the extracted DNA, $\sim 550 \mathrm{bp}$, was by conventional polymerase chain reaction. The primer set used were forward primer L16473 (5'-CTAAAAGCATCGGTCTTGTAATCC-3') and reverse primer H355 (5'-CCTGAAATGAGGAGGAACCAGATG-3') [6,9].

The PCR reaction was with a master mix prepared in the laboratory at the Institute of Primate of Research, Nairobi, Kenya. To make a $20 \mu \mathrm{l}$ reaction for each PCR reaction, $12.5 \mu \mathrm{l}$ sterile deionised water, $2 \mu \mathrm{l}$ of $5 \mathrm{X}$ PCR buffer, $2 \mu \mathrm{l}$ of $10 \mu \mathrm{m}$ dNTPs, $0.5 \mu \mathrm{l}$ of $5 \mu \mathrm{m}$ each of the forward and the reverse primers, $0.2 \mu \mathrm{l}$ of Taq DNA polymerase (New England Biolabs, UK Ltd) and $2.5 \mu \mathrm{l}$ of DNA template were used. The amplification was done in the DNA 480 Thermal cycler, Applied Biosystems USA.

The protocol for amplification of the D-loop region, adapted $[6,9]$ as follows:

Initial denaturation was for 2 minutes at $94^{\circ} \mathrm{C}, 29$ cycles of denaturation, annealing and extension for $94^{\circ} \mathrm{C}$ for 1 minute, $56^{\circ} \mathrm{C}$ for 1 minute 10 seconds and $72^{\circ} \mathrm{C}$ for 2 minutes respectively and the final extension at $72^{\circ} \mathrm{C}$ for 5 minutes. After PCR, $5 \mu \mathrm{l}$ of each of the reaction was run on $1 \%$ agarose gel stained with ethidium bromide ( 5 $\mathrm{mg} / \mu \mathrm{l})$ to verify amplification. The samples were then purified using a Qiagen PCR purification kit (Qiagen Valencia, CA USA) following manufacturer's instructions. Ninety-six PCR products were selected with correct band size and good quality and were sequenced using an automated BigDye Terminator cycle chemistry (Sanger sequencing), by Genewiz United Kingdom. The generated sequences were deposited in the GenBank with Accession Numbers: MF150204-MF150238.

\section{Genetic analysis}

The resulting sequences were edited and aligned in Bioedit version 7.1.9 software. The generated sequences were then compared with the nucleotide sequences in the GenBank using the Basic Local Alignment Search Tool (BLAST) to confirm species identity. MEGA V 7.0 [14] was used to construct the evolutionary phylogenetic trees. DNASP V5.10.01 [15] was used to calculate the haplotype diversities, nucleotide diversities and genetic differences. The Arlequin software version 3.5 [16] was used for Analysis of Molecular Variance (AMOVA) while the programme Network 5.0 version 8 was used to visualize the haplotypes in the populations using median joining tree.

\section{Results}

\section{Phylogenetic relationships}

The Neighbour-joining tree as shown in Figure 2 was constructed using maximum likelihood function based on the Tamura-Nei model [17]. The bootstrap census tree inferred from 1000 replicates is taken to represent the evolutionary history of the taxa analysed [18]. The percentage of replicate tress in which the associated taxa clustered together in the bootstrap test (1000 iterations) are shown next to the branches. Initial trees for the heuristic approach were obtained automatically by applying NeighborJoin and BioNJ algorithms to a matrix of pairwise differences estimated using the maximum likelihood function approach, and then selecting the topology with superior log likelihood value.

The phylogenetic tree indicated that the five fish populations formed one monophyletic assemblage and formed three clusters, AR3012 being very distant. Clarius liocephalus was used as an outgroup species [6]. This is confirmed to be another species as it forms a monophyletic line different from the other.

\section{Genetic variation and haplotype analysis}

A total of 33 haplotypes were detected with 60 polymorphic sites from the 433 nucleotide sites of the control region excluding $C$. liocephalus. The largest haplotype group consisted of twelve haplotypes from Baringo, followed by nine haplotypes from Athi River and Jewlett. Sagana had the lowest with four haplotypes.

The haplotype diversity $(\mathrm{Hd})$ of all the samples was $0.988 \pm 0.031$ and the nucleotide diversity $(\pi)$ was $0.02363 \pm 0.02603$ with 28 singleton variation sites and 32 parsimony informative sites.

The population at Athi River has the same number of haplotypes as Jewlett although of different types. Six haplotypes-2, 5, 7, 9, 13, and 16 occurred in more than one population as shown in Table 1. Haplotypes 5 and 9 were shared in three populations of Athi River, Kisii and Jewlett. Haplotype 2 occurred in Athi River and Sagana. Haplotype 7 occurred in Athi River and Jewlett. Haplotype 13 occurred in Jewlet and Kisii populations. Haplotype 16 occurred in Kisii and Sagana.

The haplotype distribution was drawn using median joining tree as shown in Figure 3. 


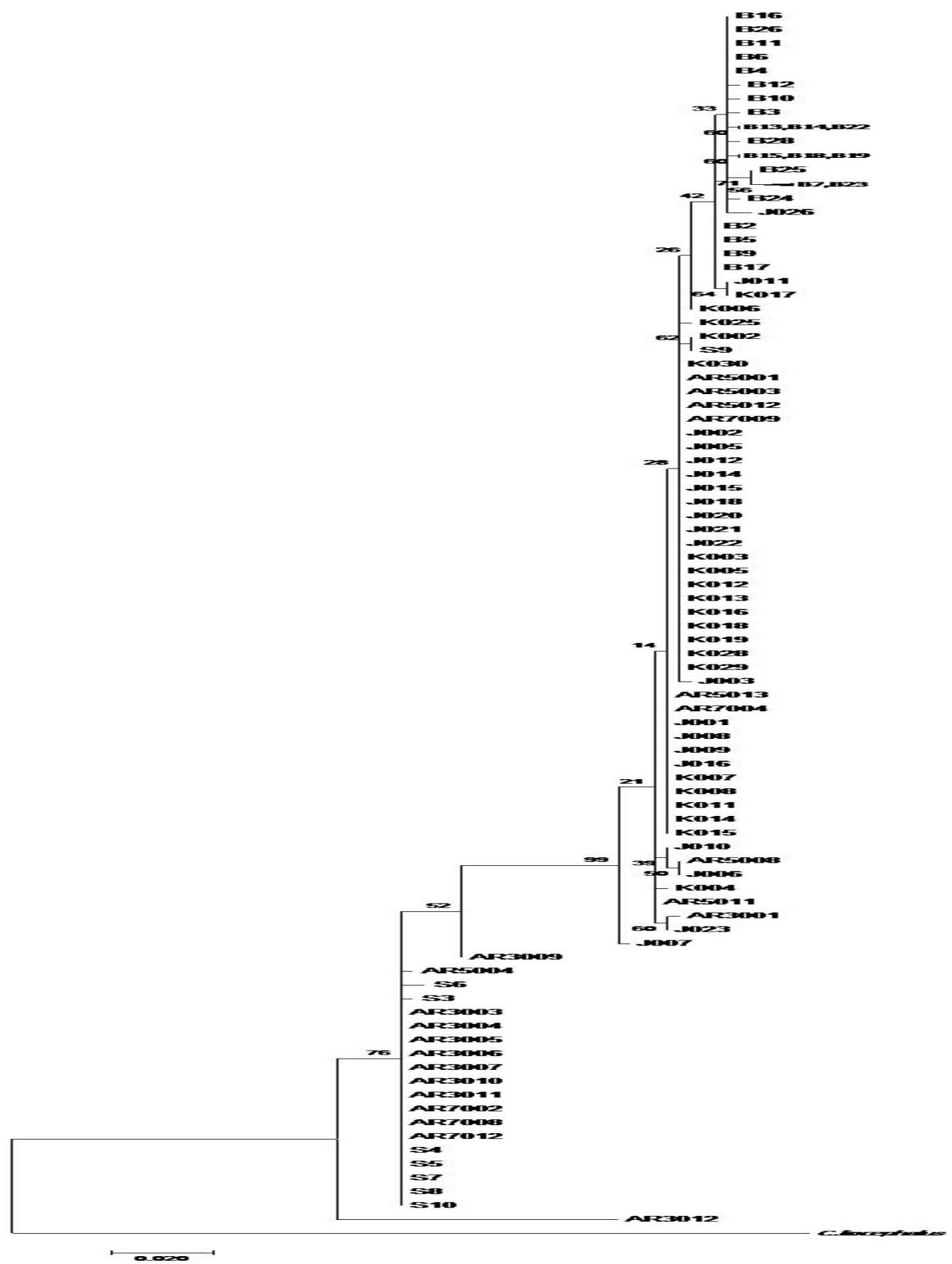

Figure 2: Molecular phylogenetic analysis of catfish samples from Kisii (K), Jewlett (J), Athi River (AR), Baringo, Sagana (S) with C. liocephalus as an outgroup constructed using maximum likelihood function based on the Tamura-Nei model.

\section{Genetic differences and AMOVA}

The overall nucleotide differences (Ks) and haplotype differences were according to Hudson et al. [19]. The pairwise differences based on haplotype and nucleotide statistics is shown in Table 2.

The AMOVA estimated $54.20 \%$ variation among populations and
$45.80 \%$ variation to be from within populations $(\mathrm{p}<0.05$; Fst 0.542$)$ as shown in Table 3.

\section{Population neutrality}

The overall Tajima's D value [20] showed non-significant negative value (Table 4) (Tajima's D was 1.02 at $\mathrm{P}>0.05$ ). The $\mathrm{D}$ value of each 
Citation: Nyunja C, Maina J, Amimo J, Kibegwa F, Harper D, et al. (2017) Stock Structure Delineation of the African Catfish (Clarius gariepinus) in Selected Populations in Kenya Using Mitochondrial DNA (Dloop) Variability. J Aquac Res Development 8: 485. doi: 10.4172/21559546.1000485

Page 4 of 6

\begin{tabular}{|c|c|c|c|c|c|c|}
\hline Haplotype & No & Athi river & Jewlett & Kisii & Sagana & Baringo \\
\hline Hap_1 & 1 & AR3001 & -- & -- & -- & -- \\
\hline Hap_2 & 15 & $\begin{array}{l}\text { AR3003, AR3004, } \\
\text { AR3005, AR3006, } \\
\text { AR3007, AR3010, } \\
\text { AR3011, AR7002, } \\
\text { AR7008, AR7012 }\end{array}$ & -- & -- & S4, S5, S7, S8, S10 & -- \\
\hline Hap_3 & 1 & AR3009 & -- & -- & -- & -- \\
\hline Hap_4 & 1 & AR3012 & -- & -- & -- & -- \\
\hline Hap_5 & 23 & $\begin{array}{l}\text { AR5001, AR5003, } \\
\text { AR5012, AR7009 }\end{array}$ & $\begin{array}{l}\mathrm{J} 002, \mathrm{~J} 005, \mathrm{~J} 012 \\
\mathrm{~J} 014 \mathrm{~J} 015, \mathrm{~J} 018 \\
\mathrm{~J} 020, \mathrm{~J} 021, \mathrm{~J} 022\end{array}$ & $\begin{array}{c}\text { K003, K005, K012, K013, K016, } \\
\text { K018, K019, K028 K029, K030 }\end{array}$ & --- & - \\
\hline Hap_6 & 1 & AR5004 & -- & -- & -- & -- \\
\hline Hap_7 & 2 & AR5008, & J006 & -- & -- & -- \\
\hline Hap_8 & 1 & AR5011 & -- & -- & -- & -- \\
\hline Hap_9 & 11 & AR5013, AR7004 & $\begin{array}{c}\mathrm{J} 001, \mathrm{~J} 008, \mathrm{~J} 009 \\
\mathrm{~J} 016\end{array}$ & K007, K008, K011, K014, K015 & -- & -- \\
\hline Hap_10 & 1 & -- & J003 & -- & -- & -- \\
\hline Hap_11 & 1 & -- & $\mathrm{J} 007$ & -- & -- & -- \\
\hline Hap_12 & 1 & -- & J010 & -- & -- & -- \\
\hline Hap_13 & 2 & -- & $\mathrm{J} 011$ & K017 & -- & -- \\
\hline Hap_14 & 1 & -- & J023 & -- & -- & -- \\
\hline Hap_15 & 1 & -- & J026 & -- & -- & --- \\
\hline Hap_16 & 2 & -- & -- & K002 & S9 & -- \\
\hline Hap_17 & 1 & -- & -- & K004 & -- & -- \\
\hline Hap_18 & 1 & -- & -- & K006 & -- & -- \\
\hline Hap_19 & 1 & -- & -- & K025 & -- & -- \\
\hline Hap_20-31 & & -- & -- & -- & -- & $\begin{array}{c}\text { B2, B5, B9, B17, B3, B4, B6, B11, } \\
\text { B16, B26, B7, B12, B13, B14, } \\
\text { B22, B15, B18, B19, B23, B24, } \\
\text { B25, B28 }\end{array}$ \\
\hline Hap_32 & 1 & -- & -- & -- & S3 & -- \\
\hline Hap_33 & 1 & -- & -- & -- & S6 & -- \\
\hline
\end{tabular}

Table 1: The table shows haplotype distribution of the African catfish from Athi River, Jewlett, Sagana, Kisii and Baringo.

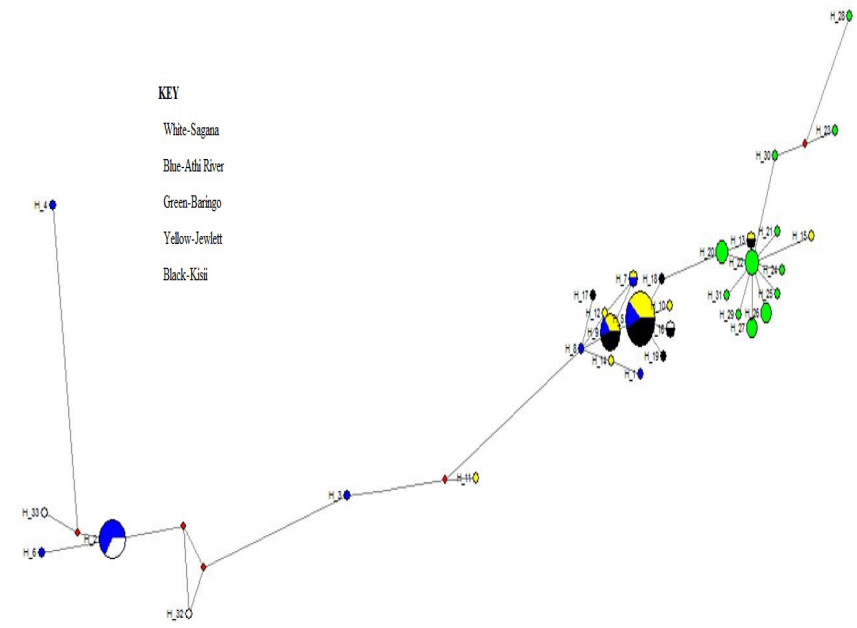

Figure 3: Median network tree of African catfish mitochondrial DNA contro region segments of Athi River, Jewlett, Sagana, Kisi and Baringo populations.

population considered individually were as shown in the Table 4 below. The $\mathrm{Fu}$ test revealed negative value of -4.45731 at an insignificant level. Kisii and Jewlett populations had relatively similar Tajima's D values, whilst Athi river was the only population that had a positive Tajima's value. The three populations Jewlett, Kisii and Baringo had no statistically significant values. Sagana had a negative significant value.

\section{Discussion}

\section{Genetic variation at the mtDNA control region}

The analysis of molecular variance demonstrated average levels of differentiation in the selected populations. The variation between populations in the current study was almost similar within populations. Although they are geographically isolated, a common origin of brood stock having been transported by humans for aquaculture purposes may have resulted in the almost equal between and within population variation.

Genetic diversity analysis revealed 33 haplotypes and 60 polymorphic sites. The number of haplotypes and polymorphic sites in the sampled

\begin{tabular}{|c|c|c|c|}
\hline Population 1 & Population 2 & Hs & Ks \\
\hline Athi River & Jewlett & 0.7768 & 8.0222 \\
\hline Athi River & Kisii & 0.7444 & 7.4658 \\
\hline Athi River & Sagana & 0.7442 & 11.1048 \\
\hline Jewlett & Kisii & 0.7447 & 1.9053 \\
\hline Jewlett & Sagana & 0.7449 & 3.4211 \\
\hline Kisii & Sagana & 0.6936 & 2.5865 \\
\hline Athi river & Baringo & 0.8457 & 7.6698 \\
\hline Jewlett & Baringo & 0.8512 & 2.5067 \\
\hline Kisii & Baringo & 0.8196 & 1.8703 \\
\hline Baringo & Sagana & 0.8530 & 3.3548 \\
\hline
\end{tabular}

Table 2: Pairwise genetic differences of the five sampled populations: Athi River Kisii, Jewlett, Sagana and Baringo. 
Citation: Nyunja C, Maina J, Amimo J, Kibegwa F, Harper D, et al. (2017) Stock Structure Delineation of the African Catfish (Clarius gariepinus) in Selected Populations in Kenya Using Mitochondrial DNA (Dloop) Variability. J Aquac Res Development 8: 485. doi: 10.4172/21559546.1000485

Page 5 of 6

\begin{tabular}{|c|c|c|c|}
\hline Source of variation & Df & Percentage of variation & P value \\
\hline Among populations & 4 & 54.20 & 0.000 \\
\hline Within populations & 88 & 45.80 & -- \\
\hline
\end{tabular}

Table 3: Hierarchical analyses of molecular variance showing amount of population genetic structure.

\begin{tabular}{|c|c|c|c|c|c|}
\hline Statistics & Athi River & Jewlett & Kisii & Sagana & Baringo \\
\hline Sample size & 22 & 20 & 20 & 8 & 23 \\
\hline Polymorphic Sites & 47 & 14 & 8 & 23 & 16 \\
\hline $\mathrm{Pi}$ & 13.05 & 2.48 & 1.32 & 5.75 & 2.34 \\
\hline Tajimas D & 0.048 & -1.35 & -1.39 & -1.84 & -1.64 \\
\hline P-value & $>0.05$ & $>0.05$ & $>0.05$ & $<0.001$ & $>0.05$ \\
\hline
\end{tabular}

Table 4: Neutrality tests of populations.

\begin{tabular}{|c|c|c|c|c|c|}
\hline Population & No. & $\begin{array}{l}\text { Polymorphic } \\
\text { sites }\end{array}$ & $\begin{array}{c}\text { No. of } \\
\text { haplotypes }\end{array}$ & $\begin{array}{l}\text { Haplotype } \\
\text { diversity (h) } \\
\text { ( } \pm \text { SD) }\end{array}$ & $\begin{array}{l}\text { Nucleotide } \\
\text { diversity (p) } \\
( \pm \text { SD) }\end{array}$ \\
\hline Athi river & 22 & 47 & 9 & $0.775 \pm 0.081$ & $0.030 \pm 0.005$ \\
\hline Kisii FPC & 20 & 8 & 7 & $0.711 \pm 0.089$ & $0.003 \pm 0.001$ \\
\hline Jewlett & 20 & 14 & 9 & $0.779 \pm 0.085$ & $0.006 \pm 0.002$ \\
\hline Sagana & 8 & 23 & 4 & $0.643 \pm 0.184$ & $0.013 \pm 0.009$ \\
\hline L. Baringo & 23 & 16 & 12 & $0.913 \pm 0.070$ & $0.006 \pm 0.003$ \\
\hline L. Victoria & 24 & 14 & 11 & $0.754 \pm 0.093$ & $0.008 \pm 0.002$ \\
\hline L. Kanyaboli & 28 & 11 & 10 & $0.741 \pm 0.064$ & $0.005 \pm 0.001$ \\
\hline
\end{tabular}

Table 5: Table showing haplotype diversity of the African catfish from four sampled hatcheries and one lake in the current study in comparison to two Kenyan lakes [6].

populations are shown in Table 5. The hatcheries had generally more polymorphic sites than the lake population. The population haplotype diversities ranged from $0.779-0.643$ accommodating 0.754 and 0.741 of Lake Victoria and Lake Kanyaboli respectively [6].

There were many private haplotypes in Athi river hatchery and Lake Baringo populations. The common haplotypes were shared between Kisii, Jewlett and Athi river hatchery populations. Lake Baringo population had slightly more haplotypes and more polymorphic sites than Lake Kanyaboli and Lake Victoria and can be attributed to mixed brood stock introduced into the lake from Sagana station. The restocking of the lake was done by Sagana research centre. Lake populations often have higher diversity than cultured populations [21]. The high diversity in Lake Baringo could indicate that brood stock of catfish in the Sagana hatchery has been from different sources, giving potentially higher diversities.

The pairwise distances indicate how different the populations were from each other. The Kisii and the Sagana population were furthest from each other while Sagana and Baringo appear to be the closest. This further confirms that brood stock may have been introduced from Sagana into Lake Baringo. The shorter the genetic distance between populations, the more probable there has been some breeding between them and the less isolated they are from one another [22]. For the nucleotide differences, Athi River and Sagana were the most distant and this was evident in the number of high polymorphic sites in the two populations.

\section{Phylogenetic structure and selection}

The Kisii, Athi River and Jewlett samples clustered together, shown by the neighbour joining tree. This indicates the strong haplotype relatedness between the three populations. Some haplotypes were shared between the three populations indicating that there could be intermingling of individuals [6]. The mixed haplotypes support that some brooders in the hatcheries could have been obtained by human transportation from the same source such as Lake Victoria hence the paraphyletic groups of Kisii and Jewlett populations. In different cases [10] the aquarium trade was mainly responsible for having brought different populations together.

The selection test indicates how much a population has significantly deviated from neutral selection [23]. In our case, the deviations were present but insignificant. This cab attributed to different hatcheries having varying management and breeding practices [7], influencing overall genetic composition of brood stock. The differences are influenced by a variety of factors including source of brood stock [7].

\section{Conclusion}

From the current study, mitochondrial DNA revealed maternal linkage of the African catfish population in Kenya as in other studies of the African catfish from lakes [6] as well as in other livestock species such as goats [24]. The phylogenetic linkage attributed to transportation of brood stock by humans for catfish production to other sites.

Athi River had the highest diversities and number of polymorphic sites hence high potential for source of brood stock for farmers rearing catfish in Kenya. The exploitation of cultured C. gariepinus for baits can reduce the pressure on the wild populations. The levels of genetic diversity in the study can be used by the management of cultured populations to reduce chances of inbreeding in the populations and inform selection programmes. Lake Baringo also provides a potential source of diverse brood stock for use in brood stock selection pogrammes.

\section{References}

1. Vernon D, Someren $V(1960)$ The inland fishery research station, Sagana Kenya. Nature.

2. Hecht T, Uys W, Britz PJ (1988) Culture of sharptooth catfish, Clarias gariepinus in Southern Africa. Foundation for Research Development: CSIR.

3. Shoko AP, Limbu SM, Mgaya YD (2016) Effect of stocking density on growth performance, survival, production and financial benefits of African sharptooth catfish (Clarias gariepinus) monoculture in earthen ponds. J Appl Aquaculture 28: 220-234.

4. Otieno MJ (2011) Fishery value chain analysis: Background Report-Kenya FAO, Rome, Italy.

5. Musa S, Aura CM, Owiti G, Nyonje B, Orina P, et al. (2012) Fish farming enterprise productivity program (FFEPP) as an impetus to Oreochromisniloticus (L.) farming in Western Kenya: Lessons to learn. Afr J Agric Res 7: 1324-1330.

6. Barasa JE, Abila R, Grobler JP, Dangasuk OG, Njahira MN, et al. (2014) Genetic diversity and gene flow in Clarias gariepinus from Lakes Victoria and Kanyaboli, Kenya. Afr J Aquat Sci 39: 287-293.

7. Orina PS, Maina JG, Wangia SM, Karuri EG, Mbuthia PG, et al. (2014) Situational analysis of Nile tilapia and African catfish hatcheries management: A case study of Kisii and Kirinyaga counties in Kenya. Livestock Research for Rural Development 26: 5 .

8. Munguti JM, Kim JD, Ogello EO (2014) An Overview of Kenyan aquaculture: Current Status, challenges, and opportunities for future development. Fish Aquat Sci 17: 1-11.

9. Nazia AK, Suzana M, Azhar H, Nguyen TTT, Azizah S (2010) No genetic differentiation between geographically isolated populations of Clarias macrocephalus Günther in Malaysia revealed by sequences of mtDNA cytochrome b and D-loop gene regions. J Appl Ichthyol 26: 568-570.

10. Wu LW, Liu CC, Lin SM (2011) Identification of exotic sailfin catfish species (Pterygoplichthys Loricariidae) in Taiwan Based on Morphology and mtDNA Sequences. Zool Stud 50: 235-246.

11. Liu ZJ, Cordes JF (2004) DNA marker technologies and their applications in aquaculture genetics. Aquaculture 238: 1-37.

12. Kallqvist $T$ (1987) Primary production and phytoplankton in Lake Baringo and Naivasha, Kenya. Norwegian Institute for Water Research Report, Blinden, Oslo. 
Citation: Nyunja C, Maina J, Amimo J, Kibegwa F, Harper D, et al. (2017) Stock Structure Delineation of the African Catfish (Clarius gariepinus) in Selected Populations in Kenya Using Mitochondrial DNA (Dloop) Variability. J Aquac Res Development 8: 485. doi: 10.4172/21559546.1000485

Page 6 of 6

13. Britton JR, Harper DM (2005) Assessing the true status of the fish species Labeo cylindricus (Peters 1868) (Teleostei: Cyprinidae) in Lake Baringo Kenya African. J Aquat Sci 30: 203-205.

14. Kumar S, Stecher G, Tamura K (2016) MEGA7: Molecular Evolutionary genetics analysis version 7.0 for bigger datasets. Mol Biol Evol: msw054.

15. Librado P, Rozas J (2009) DnaSP v5: A software for comprehensive analysis of DNA polymorphism data. Bioinformatics 25: 1451-1452.

16. Excoffier L, Lischer HE (2010) Arlequin suite version 3.5: A new series of programs to perform population genetics analyses under Linux and Windows. Mol Ecol Res 10: 564-567.

17. Tamura K, Nei M (1993) Estimation of the number of nucleotide substitutions in the control region of mitochondrial DNA in humans and chimpanzees. Mol Biol Evol 10: 512-526.

18. Felsenstein J (1985) Confidence limits on phylogenies. An approach using the bootstrap. Evolution 39: 783-791.
19. Hudson RR, Slatkin M, Maddison WP (1992) Estimation of levels of gene flow from DNA sequence data. Genetics 132: 583-589.

20. Tajima $F$ (1989) Statistical method for testing the neutral mutation hypothesis by DNA polymorphism. Genetics 123: 585-595.

21. Li Q, Park C, Endo T, Kijima A (2004) Loss of genetic variation at microsatellite loci in hatchery strains of the Pacific abalone ((Haliotis discus hannai). Aquaculture 235: 207-222.

22. Wright S (1943) Isolation by distance. Genetics 28: 139-156.

23. Maggio T, Andaloro MF, Arculeo M (2006) Genetic population structure of Epinephelus marginatus (Pisces, Serranidae) revealed by two molecular markers. Ital J Zool 73: 275-283.

24. Kibegwa FM, Githui KE, Jung'a JO, Badamana MS, Nyamu MN (2015) Mitochondrial DNA variation of indigenous goats in Narok and Isiolo counties of Kenya. J Anim Breed Genet 133: 238-247. 